\title{
Comunicação
}

\section{Influence of leaf retention on cutting propagation of Lavandula dentata $\mathrm{L}$.}

\author{
Claudine Maria de Bona ${ }^{1}$, Luiz Antonio Biasi²
}

\begin{abstract}
Vegetative propagation of lavender offers several advantages over sexual propagation, among them crop homogeneity and yield of higher quality essential oil. However, Lavandula species have been propagated mostly by seeds and are said to be recalcitrant to rooting when propagated by cuttings. During cutting propagation, one of the important variables that influence the rooting capacity of cuttings is the leaf retention. The objective of this work was to evaluate the influence of leaf retention on rooting of $L$. dentata cuttings. Apical cuttings of $L$. dentata of $10 \mathrm{~cm}$ in length, keeping approximately $1 / 3,1 / 2$ or $2 / 3$ of their leaves were planted in commercial substrate Plantmax HT ${ }^{\circledR}$ under intermittent mist. After two months, averages of root number, length of the longest root, root fresh and dry weights, and the survival percentage were evaluated. Root length and fresh weight were statistically greater with 2/3 of leaf retention and when fewer leaves were kept on the cuttings, lower means of root dry weight was observed. Under the conditions applied in this study, greater leaf retention was better for rooting of $L$. dentata cuttings.
\end{abstract}

Key words: Lavender, rooting, vegetative propagation,.

\section{RESUMO}

\section{Influência da retenção foliar na estaquia de Lavandula dentata $\mathbf{L}$.}

A propagação vegetativa da alfazema oferece muitas vantagens comparada à propagação sexuada entre elas, homogeneidade da lavoura e produção de óleo essencial de melhor qualidade. Todavia, espécies de Lavandula têm sido propagadas principalmente por sementes e são consideradas recalcitrantes ao enraizamento na propagação por estaquia. Durante a propagação por estaquia, uma das importantes variáveis que influenciam na capacidade de enraizamento das estacas é a retenção foliar. O objetivo deste trabalho foi avaliar a influência da retenção de folhas no enraizamento de estacas de $L$. dentata. Estacas apicais de $L$. dentata de $10 \mathrm{~cm}$ de comprimento, mantendo 1/3, 1/2 ou 2/3 de suas folhas, foram plantadas em substrato comercial Plantmax HT® sob nebulização intermitente. Após dois meses, médias de número de raízes, comprimento da raiz mais longa, massas fresca e seca de raízes e percentagem de sobrevivência foram avaliados. Comprimento e massa de matéria fresca das raízes foram estatisticamente superiores sob 2/3 de retenção foliar, e quando menos folhas foram mantidas, menor média de massa de matéria seca de raízes foi observada. Nas condições utilizadas, a maior retenção de folhas causou melhor desenvolvimento das raízes de estacas de $L$. dentata.

Palavras-chave: Alfazema, enraizamento, propagação vegetativa.

Recebido para publicação em julho de 2009 e aprovado em abril de 2010

${ }^{1}$ Engenheira-Agrônoma, Ph. Doctor. Instituto Agronômico do Parana (IAPAR), Rua Maximo João Kopp 274, Bloco 1, Ala Sul, Centro Administrativo do Governo do Estado, Santa Cândida, 82630-900, Curitiba, PR, Brasil. debona@iapar.br

${ }^{2}$ Engenheiro-Agrônomo, Doutor. Departamento de Fitotecnia e Fitossanitarismo, Universidade Federal do Paraná, C.P. 19061, 81531-990, Curitiba, PR, Brasil. biasi@ufpr.br. Author for correspondence. 


\section{INTRODUCTION}

Lavandula dentata, a herbaceous small shrub belonging to the Labiaceae family (Cavanagh \& Wilkinson, 2002), is a very productive Lavandula species, rich in 1,8-cineol, fenchol and camphor (Echeverrigaray et al., 2005). The disinfectant and medicinal properties of lavender can be used in different market sectors, such as the cosmetics and industrial fragrance industries, among others (Al-Amier et al., 1999; Shellie et al., 2002; Moss et al., 2003; Beus, 2006; Chemat et al., 2006; Dob et al., 2006; Singh et al., 1997).

Unfortunately, the commercial oil composition of Lavandula varies tremendously mostly because of the great genetic variation due to segregation caused by sexual propagation (Nogueira \& Romano, 2002), since the species have been propagated mostly by seeds because of the well known rooting recalcitrance of cuttings, which has been attributed to the genus (Dias et al., 2002; Nogueira \& Romano, 2002; Sousa et al., 2005; Tyub et al., 2007). Nevertheless, these are herbaceous plants and according to Hartmann et al. (2002), rooting tends to be easily induced in herbaceous species.

Vegetative propagation offers several advantages compared to the sexual propagation, among them the homogeneity of plant material, crop and subproducts, rate of plant development and productivity since healthy, superior adult stock plants are used and the clonal propagation of the plant material increases the chances of obtaining higher quality essential oil (Tyub et al., 2007).

Cutting propagation has been used to propagate many aromatic and medicinal plants (Biasi \& Costa, 2003; Bona et al., 2004, Bona et al., 2005; Sousa et al., 2005; Carvalho et al., 2007; Costa et al., 2007; Maia et al., 2008). During cutting propagation, one of the important variables which is supposed to influence the rooting capacity of cuttings is leaf retention, because leaves hold auxin, a small signaling molecule which is translocated to the cutting base, allowing production of carbohydrates by photosynthesis (Hartmann et al., 2002; Bordin et al., 2005), and acting as a trigger to the developmental process of rhizogenesis (Robert \& Friml, 2009). However, the foliar area left on the cutting, if excessive, may cause an undesirable effect on rooting due to possible dehydration of cuttings caused by excessive evaporation, even under mist (Hartmann et al., 2002; Lima et al., 2006).

The objective of this work was to evaluate the influence of leaf retention on rooting of $L$. dentata cuttings.

\section{MATERIALAND METHODS}

Herbaceous apical cuttings of $10 \mathrm{~cm}$ in length and approximately $0.5 \mathrm{~cm}$ in diameter were cut at the end of winter from the apical part of stems of adult (approximately two year-old) $L$. dentata stock plants, with $1 / 3,1 / 2$, or $2 / 3$ of their top leaves kept intact. The cuttings were placed in commercial substrate Plantmax ${ }^{\circledR}$ in polystyrene foam trays with 128 (cells volume $35 \mathrm{~cm}^{3}$ ) and kept under an intermittent mist system $\left(20 \pm 7^{\circ} \mathrm{C}\right.$ and 15 seconds mist with 15 minutes interval from 8:00 to 17:00, 60 minutes interval from 17:00 to 22:00, or 180 minutes from 22:00 to 08:00). A voucher specimen was deposited in the herbarium of the UFPR's Department of Botany (excicata nº UPCB 61.305). A total of 96 cuttings (eight cuttings per treatment and four replications) were used. A completely randomized experimental design was applied. After two months, means of root number, length of the longest root, root fresh and dry weight and survival percentage were compared using the Bartlett test to assess equality of variance and Tukey's post-test pd”0.05 using the 2.10 MSTAT-C ${ }^{\circledR}$ software.

\section{RESULTS AND DISCUSSION}

One hundred percent of cuttings were rooted in all treatments. Root length and fresh weight were statistically greater with 2/3 of leaf retention, whereas cuttings with fewer leaves had lower mean root dry weight (Table 1) probably due to less carbohydrate production, showing that a greater leaf retention was important for rooting of this genotype, although it is usually propagated with just a few apical leaves left in order to avoid cutting dehydration. The leaf size reduction procedure is quite usual, to reduce water loss. However, retention of the maximum leaf area possible may produce a stronger root system in a shorter period, because root initiation and growth require adequate oxygen supply. Larger leaf areas may allow better photosynthetic performance of cuttings and serve as source of auxin and co-factors to initiate and improve rooting, because differential auxin accumulation is perceived and interpreted, at the level of cells of the wounded tissues by nuclear auxin signaling pathway, which regulates gene expression and reprogramming of cell fates (Robert \& Friml, 2009). As a general rule, maximum leaf area should still be retained (Hamilton \& Midcap, 2003).

Lack of adequate leaf retention may be one of the reasons why some species are labeled as difficult to root and that might be the case for some Lavandula species. Garbuio et al. (2007) also observed the importance of leaf retention as leafy patchouli (Pogostemon cablin) cuttings showed a greater rooting percentage than leafless cuttings. Passiflora alata leafy cuttings showed greater rooting percentage than cuttings with leaves cut by half or leafless (Meletti et al., 2007). Tarragó et al. (2005) also reported a strong correlation between leaf retention and rooting on softwood cuttings of Ilex paraguariensis. 
Table 1. Effect of leaf retention on root number, length, fresh and dry weigths of $L$. dentata cuttings.

\begin{tabular}{lcccc}
\hline Foliar retention & Root number & $\begin{array}{c}\text { Root lenght } \\
(\mathbf{c m})\end{array}$ & $\begin{array}{c}\text { Fresh weigth } \\
\text { of roots } \mathbf{( g )}\end{array}$ & $\begin{array}{c}\text { Dry weight } \\
\text { of roots (g) }\end{array}$ \\
\hline $2 / 3$ & $20,50 \mathrm{a}^{2}$ & $12,70 \mathrm{a}$ & $4,76 \mathrm{a}$ & $0,59 \mathrm{a}$ \\
$1 / 2$ & $21,35 \mathrm{a}$ & $9,77 \mathrm{~b}$ & $3,43 \mathrm{~b}$ & $0,27 \mathrm{ab}$ \\
$1 / 3$ & $14,94 \mathrm{a}$ & $9,00 \mathrm{~b}$ & $1,60 \mathrm{c}$ & $0,11 \mathrm{~b}$ \\
C.V.(\%) & 25,3 & 9,6 & 20,5 & 8,4 \\
\hline
\end{tabular}

${ }^{1}$ Original data transformed into $\sqrt{(\mathrm{x}+1)}$.

${ }^{2}$ Mean values on same column followed by the same letters are not statistically different according to Tukey's test at 5\% probability.

Presence of leaves influences rooting, mainly on herbaceous and semi hardwood cuttings, in which a growing shoot tip, or lateral bud, is important, since such cuttings, differently from hardwood cuttings taken during rest periods, have low reserve supplies. Some root promoting compounds (auxin, cofactors) present in buds and leaves travels through the phloem to the base of the cuttings and exerts stimulating effect on rooting. On the other hand, dehydration caused by transpiration may occur when leaves are kept on cuttings (Hartmann et al., 2000; Robert \& Friml, 2009).

The rooting observed in this study was probably benefited by translocation of auxin and cofactors, and photosynthetic performance, from leaves kept on the cuttings. Root initiation is dependent on auxin, carbohydrates and nitrogen status, carbon/nitrogen ratio, as well as rooting co-factors (phenolics; possibly an orthodyhydroxy phenol and a polyphenol-oxidase) and auxin synergists, which are supplied by leaves and accumulate at the cutting base (Hartmann et al., 2002; Robert \& Friml, 2009). As a general rule, presence of leaves is important when using herbaceous or semi-hardwood cuttings for propagation. However, some species may present an opposite response to leaf presence. For instance, Ligustrum sinenses leafless semi-hardwood cuttings rooted better than leafy ones (Bona et al., 2002). On the other hand, for Aristolochia triangularis herbaceous cuttings, the presence of leaves was indispensable for rooting (Correa \& Biasi, 2003).

\section{CONCLUSIONS}

L. dentata cuttings root easily.

For the conditions tested in this study, 2/3 leaf retention improved rooting of $L$. dentata cuttings.

\section{REFERENCES}

Al-Amier H, Mansour BMM, Toaima N, Korus RA \& Shetty K (1999) Tissue culture based screening for selection of high biomass and phenolic producing clonal lines of lavender using Pseudomonas and azetidine-2-carboxylate. Journal of Agricultural and Food Chemistry, 47:2937-2943.

Beus C (2006) Growing and marketing lavender. Washington, Washington State University. 28p.
Biasi LA \& Costa G (2003) Propagação vegetativa de Lippia alba. Ciência Rural, 33:455-459.

Bona CM, Biasi LA, Zanette F \& Nakashima T (2005) Estaquia de três espécies de Baccharis. Ciência Rural, 35:223-226.

Bona CM, Biasi LA, Zanette F \& Nakashima T (2004) Propagação de três espécies de carqueja com estacas de diferentes tamanhos. Semina: Ciências Agrárias, 25:179-184.

Bona CM, Hoger Filho G, Augusto CSS \& Biasi LA (2002) Propagação de Ligustrum sinenses por estaquia lenhosa. Scientia Agraria, 3:25-28.

Bordin I, Hidalgo PC, Bürkle R \& Roberto SR (2005) Efeito da presença da folha no enraizamento de estacas semilenhosas de porta-enxertos de videira. Ciência Rural, 35:215-218.

Carvalho RIN, Nolasco MA, Carvalho T, Ripka M, Giublin LM, Negrello M \& Scheffer MC (2007) Enraizamento de estacas de carqueja em função de diferentes substratos e posições do ramo em plantas masculinas e femininas. Scientia Agraria, 8:269274.

Cavanagh HMA \& Wilkinson JM (2002) Biological activities of lavender essential oil. Phytotherapy Research, 16:301-308.

Chemat F, Lucchesi ME, Smadja J, Favretto L, Colnaghi G \& Visinoni F (2006) Microwave accelerated steam distillation of essential oil from lavender: a rapid, clean and environmentally friendly approach. Analytica Chimica Acta, 555:157-160.

Correa CF \& Biasi LA (2003) Área foliar e tipo de substrato na propagação por estaquia de cipó-mil-homens (Aristolochia triangularis Cham. Et Schl.). Revista Brasileira de Agrociência, 9:233-235.

Costa LCB, Pinto JEBP \& Bertolucci SKV (2007) Comprimento da estaca e tipo de substrato na propagação vegetativa de atroveran. Ciência Rural, 37:1157-1160.

Dias MC, Almeida R \& Romano A (2002) Rapid clonal multiplication of Lavandula viridis L'H'er through in vitro axillary shoot proliferation. Plant Cell, Tissue and Organ Culture, 68:99-102.

Dob T, Dahmane, D, Agh M \& Chelghoum C (2006) Essential oil composition of Lavandula stoechas from Algeria. Pharmaceutical Biology, 44:60-64.

Druege U, Zerche, S, Kadner R \& Ernst M (2000) Relation between nitrogen status, carbohydrate distribution and subsequent rooting of chrysanthemum cuttings as affected by pre-harvest nitrogen supply and cold storage. Annals of Botany, 85:687-701.

Echeverrigaray S, Basso R \& Andrade LB (2005) Micropropagation of Lavandula dentata from axillary buds of field-grown adult plants. Biologia Plantarum, 49:439-442.

Garbuio C, Biasi LA, Kowalski APJ, Signor D, Machado EM \& Deschamps C (2007) Propagação por estaquia em patchouli com diferentes números de folhas e tipos de estaca. Scientia Agraria, 8:435-438. 
Hamilton DF \& Midcap JT (2003) Propagation of woody ornamentals by cuttings. In: Florida Cooperative Extension Service, Institute of Food and Agricultural Sciences, University of Florida. Disponível em:<http://edis.ifas.ufl.edu>. Acessado em 16 de março de 2009.

Hartmann HT, Kester DE, Davies Junior FT \& Geneve RL (2002) Plant Propagation: Principles and Practices. $7^{\mathrm{a}}$ ed. New Jersey, Prentice Hall. 880p.

Lima RLS, Siqueira DL, Weber OB \& Cazetta JO (2006) Comprimento de estacas e parte do ramo na formação de mudas de aceroleira. Revista Brasileira de Fruticultura, 28:83-86.

Maia SSS, Pinto JEBP, Silva FN \& Oliveira C (2008) Enraizamento de Hyptis suaveolens (L.) Poit. (Lamiaceae) em função da posição da estaca no ramo. Revista Brasileira de Ciências Agrárias, 3:317-320.

Meletti LMM, Barbosa W, Pio R, Tucci MLS, Costa AB \& Feldberg NP (2007) Influence of season, leaf presence and indolebutyric acid on the rooting potential of sweet passion-fruit (Passiflora alata Curtis) cuttings. Revista UDO Agrícola, 7:68-73.

Moss M, Cook J, Wesnes K \& Duchett P (2003) Aromas of rosemary and lavender essential oils differentially affect cognition and mood in healthy adults. International Journal of Neuroscience, 113:15-38.
Nogueira JMF \& Romano A (2002) Essential oils from micropropagated plants of Lavandula viridis. Phytochemical Analysis, 13:4-7.

Robert HS \& Friml J (2009) Auxin and other signals on the move in plants. Nature Chemical Biology, 5:325-332.

Shellie R, Mondello L, Marriott P \& Dugo G (2002) Characterization of lavender essential oils by using gas chromatography - mass spectrometry with correlation of linear retention indices and comparison with comprehensive two-dimensional gas chromatography. Journal of Chromatography, 970:225-234.

Singh AK, Singh J, Singh SP \& Sharma S (1997) Genetic divergence among 43 lavender (Lavandula officinalis Chaix) clones evaluated over environments. Crop Improvements, 24:101-104.

Sousa PBL, Ayala-Osuna JT \& Gomes JE (2005) Propagação vegetativa de Ocimum gratissimum L. em diferentes substratos. Revista Brasileira de Plantas Medicinais, 8:39-44.

Tarragó J, Sansberro P, Filip R, López P, González A, Luna C \& Mroginski L (2005) Effect of leaf retention and flavonoids on rooting of Ilex paraguariensis cuttings. Scientia Horticulturae, 103:479-488.

Tyub S, Kamili AN \& Shah AM (2007) Effect of BAP on shoot regeneration in shoot tip cultures of Lavandula officinalis. Journal of Research \& Development, 7:125-130. 